Original Contribution

\title{
INFLUENCE OF THE ADDITION OF BREAD WASTES BY FEEDING OF GUINEA FOWLS - LAYERS ON THE CLARCS OF ENERGY DISTRIBUTION/PROTEIN TRANSFORMATION
}

\author{
D. Penkov*, M. Dimitrova, R. Ivanova \\ Agricultural University, Plovdiv, Bulgaria
}

\begin{abstract}
AIM: establishing of the net transformation of the energy and the protein in the eco-technical chain "fodder-egg mélange" by replacement of the $10 \%$ of the grain component of the combined fodder for Guinea fowls - layers with bread wastes.

MATERIAL AND METHODS: 2 groups - control (without bread wastes) and experimental - 10\% replacement of wheat with bread wastes.

RESULTS: For the Clarc of energy distribution (ME fodder-GE egg mélange) - control group - 0.1410, with $10 \%$ bread wastes -0.1415 ; for the Clarc of protein transformation (CPfodder-CP mélange) respectively 0.1654 and 0.1720 . For both of the indexes the bird consumed $10 \%$ bread wastes have significant higher energy and protein net utilization.
\end{abstract}

Key words: Bread wastes, Clarc of energy distribution, Clarc of protein transformation, Guinea fowls

\section{INTRODUCTION}

Guinea fowl (Numida meleagris) is a source of meat and eggs, highly valued by consumers for their taste, nutrition and dietary qualities. In many West African countries, guinea fowl is the second most important source of meat and eggs after chicken species $(1,2)$.

There is a growing interest in rearing guinea fowl in some European countries and especially in France, Belgium and the Scandinavian countries (3).

The biotransformation of feed into humanedible products is expressed by the term 'feed conversion'. In egg-laying poultry farming, it is most often specified as 'feed consumption per egg or per kg of egg weight' (4-6).

The net transformation of nutrients and energy from feed to human-edible animal products is the most accurate indicator for reporting the efficiency of animal production (7).

Identifying a system for accurate reporting of that net transformation is increasingly

\footnotetext{
*Correspondence to: Dimo Penkov, Agricultural University - 4000 Plovdiv, 12 D. Mendeleev Str., Bulgaria,E-mail: dimopenkov@gmail.com
}

necessary. Penkov and Genchev (8) introduced and standardized two main indices for reporting those processes in poultry farming for meat production - Clarc of Energy Distribution (CED) and Clarc of Protein Transformation (CPT). The basis of the indices (Clarc(s) was borrowed from the cycle of the chemical elements in their transfer along the trophic chain $(9,10)$.

Birds are competitors of humans for cereal grain foods and that is why alternative sources should be found to provide for the nutrition of fowl. Such potential sources (mainly energy) are the by-products of the bakery industry (bread waste). Some authors (11-13) reported that bread waste can be included up to $10 \%-20 \%$ in broiler feed without having a negative effect on their productivity.

The aim of the present study was to establish the effect of replacing $10 \%$ of wheat grain with bread waste in compound feed for guinea fowl.

\section{MATERIAL AND METHODS}

The experiment was carried out at the Training and Experimental Fields of the Agricultural University - Plovdiv in 2020. Two groups of 32 pearl-gray guinea fowl of a local population in the second egg-laying year were used in the 
experiment. The birds were divided into an experimental and a control group. Four male guinea fowl were placed in each group for natural stimulation of egg-laying. The birds from both groups were raised free-range, in a light-type polymer premises open to free-range yards (volière type). $10 \%$ of the wheat grain in the feed of the experimental group was replaced with bread waste - Table 1. Taking into account the nutritional value of bread waste (14), we equalized the isoenergetic and isoprotein diet of the two groups. The experimental feed was offered two weeks before the expected start of
PENKOV D., et al. the egg-laying period and the experiment continued throughout egg-laying.

The length of the egg-laying period, the average laying capacity and morphometric parameters of the eggs, as well as the average consumption of compound feed per laying hen from the experimental and control groups were reported. During the experiment, the laying capacity and feed residues were monitored daily. The morphological parameters of eggs were monitored weekly on $10 \%$ of the laid eggs. The yolk and albumen weights were measured with an OHAUS-2000 electronic scale with an accuracy of $0.01 \mathrm{~g}$.

Table 1. Component composition of feed for laying Guinea fowls

\begin{tabular}{lcc}
\hline Compounds, \% & $\begin{array}{c}\text { Experimental group (10\% } \\
\text { bread wastes) }\end{array}$ & Control group \\
\hline Maize & 30.00 & 30.00 \\
Wheat & 20.00 & 30.00 \\
Bread wastes & 10.00 & - \\
Soybean meal 44\% CP & 20.32 & 20.32 \\
Sunflower meal 34\% CP & 6.00 & 6.00 \\
L-lysine HCL & 0.17 & 0.17 \\
DL-methionine & 0.15 & 0.15 \\
Limestone & 8.14 & 8.14 \\
Calcium phosphate & 1.95 & 1.95 \\
Salt & 0.12 & 0.12 \\
Vitamin-mineral premix & 0.65 & 0.65 \\
Sunflower oil & 2.50 & 2.50 \\
Nutritive values (native fodder): & & \\
ME, MJ/kg & 11.73 & 11.73 \\
Crude protein, \% & 16.50 & 16.50 \\
Lysine - \% & 0.80 & 0.80 \\
Methionine+cystine -\% & 0.75 & 0.75 \\
Ca - \% & 4.02 & 4.02 \\
P, avail. - \% & 0.44 & 0.44 \\
Na - \% & 0.18 & 0.18 \\
\hline
\end{tabular}

The protein, fat and ash contents were determined by the Weende method (15). The gross energy content (GE-MJ) was determined by the formula of Schiemann et al.(16):

$\mathrm{GE}=0.0242 * \mathrm{CP}+0.0366 * \mathrm{CF}+$ $0.0170^{*} \mathrm{CNFE}$, where $\mathrm{CP}, \mathrm{CF}, \mathrm{NFE}$ are the crude protein, crude fat and nitrogen-free extracts in grams.

The Clarcs of Energy Distribution (CED) and Protein Transformation (CPT) are calculated according to the formulas cited by Penkov and Grigorova (17):

CED = Gross energy in the egg albumen/yolk/melange produced by a laying hen for the whole experimental period/Metabolizable energy from the feed consumed for the whole experimental period; $\mathrm{CPT}=$ Crude protein in the egg albumen/yolk/melange produced by a laying hen for the whole experimental period/Crude protein from the feed consumed for the whole experimental period.

The results were processed in EXCEL - Data analysis.

\section{RESULTS AND DISCUSSION}

Table 2 presents the data for calculation of the nutrients intake at the system entrance. 
Table 2. Fodder, metabolizable energy (ME) and crude protein $(C P)$ intake of control and experimental group (mean from 1 layer for the whole experimental period) - system entrance

\begin{tabular}{lllll}
\hline Indexes & \multicolumn{3}{c}{$\begin{array}{c}\text { Exper. group (with } \\
\text { bread wastes) }\end{array}$} & \multicolumn{2}{c}{ Control group } \\
\cline { 2 - 5 } & SEM & SD & SEM & SD \\
Fodder consumed for the period $-\mathrm{g}$ & & & & \\
ME intake for the period - MJ & 9632.37 & 173.08 & 9568.15 & 165.48 \\
Crude protein intake for the period $-\mathrm{g}$ & 112.99 & 2.03 & 112.23 & 1.94 \\
\hline
\end{tabular}

The average feed intake per laying guinea fowl for the whole reproductive period was relatively the same in both groups -9632.37 and 9568.15 for the experimental and control groups, respectively. On that basis, no significant differences were observed in the amounts of metabolizable energy intake (MEI) - 112.99 MJ (experimental group) and 112.23 MJ (control group) and crude protein - $1589.34 \mathrm{~g}$ and $1573.96 \mathrm{~g}$, respectively.

Compared to data obtained in the study of Angelov (18), the lower feed consumption in both groups should be noted. The lower feed intake can be explained by the fact that guinea fowl in the present experiment were free-range, with an access to yards with rich edible flora and fauna, as opposed to intensively bred ones.

Table 3. Chemical composition and gross energy content in $1 \mathrm{~kg}$ egg white and yolk from experimental and control group

\begin{tabular}{lcccc}
\hline Indexes & \multicolumn{3}{c}{$\begin{array}{c}\text { Exper. group (with } \\
\text { bread wastes) }\end{array}$} & \multicolumn{2}{c}{ Control group } \\
\cline { 2 - 5 } & SEM & SD & SEM & SD \\
Crude protein in native egg white - $\%$ & 10.66 & 0.23 & 10.43 & 0.21 \\
Crude fats in native egg white - $\%$ & 0.064 & 0.01 & 0.068 & 0.02 \\
NFE in native egg white - \% & 1.92 & 0.10 & 1.89 & 0.07 \\
Gross energy in native egg white - MJ & 2.60 & 0.13 & 2.87 & 0.06 \\
Crude protein in native egg yolk - \% & 11.00 & 0.19 & 11.13 & 0.13 \\
Crude fats in native egg yolk - \% & 25.59 & 0.42 & 25.57 & 0.37 \\
NFE in native egg yolk - \% & 1.93 & 0.13 & 1.97 & 0.09 \\
Gross energy in native egg yolk - MJ & 12.36 & 0.20 & 12.39 & 0.18 \\
\hline
\end{tabular}

Table 3 presents the chemical composition and the content of crude protein and crude fat in the egg albumen and yolk of the experimental guinea fowl eggs. The values were 10.66 for the percentage of crude protein contained in the native protein in the experimental group and 10.43 for the control group, respectively. The crude fat content was 0.064 (experimental group) and 0.068 (control group). The values of crude protein in the yolk were 11.00 versus 11.13 in the control. As with the other presented values of the indicators, the crude fat content in the yolk in the two groups, did not differ significantly -25.59 and 25.57 , respectively ( $p$ $>0.05$ ). In the studies carried out on the chemical composition of guinea fowl eggs, Song et al. (19) reported crude protein values of 10.61 in the albumen and higher mean values in the yolk - 15.74, as well as higher values of crude fat -0.13 and 31.91 , respectively. The results also corresponded to those reported by $(18,20)$.

The gross energy in the native protein was 2.60 MJ in the experimental group, fed with bread waste added to feed, and the value in the control group was slightly higher $-2.87 \mathrm{MJ}$. In the yolk, the values of gross energy were almost equal 12.36 versus $12.39 \mathrm{MJ}$, respectively.

Table 4 presents the amounts of albumen and yolk produced by the experimental and the control groups, the gross energy, and the crude protein produced on average by a layer from each group. The results show that more eggs were obtained in the experimental group (with bread waste added to feed) - an average of 57 eggs versus 38 in the control group. That is the main reason for the production of more protein $-1534.56 \mathrm{~g}$ versus $1505.51 \mathrm{~g}$ and yolk -973.21 $\mathrm{g}$ versus $923.93 \mathrm{~g}$. 
PENKOV D., et al.

Table 4. Mean mass of the egg whitelyolk, gross energy and crude protein, produced from 1 layer for the whole experimental period and Clarcs of distribution/transformation

\begin{tabular}{|c|c|c|c|c|}
\hline \multirow[t]{2}{*}{ Indexes } & \multicolumn{2}{|c|}{$\begin{array}{l}\text { Exper. group (with } \\
\text { bread wastes) }\end{array}$} & \multicolumn{2}{|c|}{ Control group } \\
\hline & SEM & SD & SEM & SD \\
\hline Produced egg white - mean from 1 layer, $g$ & 1534.56 & 31.65 & 1505.51 & 19.01 \\
\hline Produced egg yolk - mean from 1 layer, $g$ & 973.21 & 18.05 & 929.93 & 13.19 \\
\hline $\begin{array}{l}\text { Produced gross energy from the egg white from } 1 \\
\text { layer for the whole exper.period - MJ }\end{array}$ & 3.99 & 0.15 & 4.32 & 0.10 \\
\hline $\begin{array}{l}\text { Produced gross energy from the egg yolk from } 1 \\
\text { layer for the whole exper.period - MJ }\end{array}$ & 12.01 & 0.46 & 11.52 & 0.25 \\
\hline $\begin{array}{l}\text { Produced crude protein from the egg white from } 1 \\
\text { layer for the whole exper.period }-\mathrm{g}\end{array}$ & 163.58 & 9.78 & 157.02 & 5.73 \\
\hline $\begin{array}{l}\text { Produced crude protein from the egg yolk from } 1 \\
\text { layer for the whole exper.period }-\mathrm{g}\end{array}$ & 107.05 & 8.64 & 103.50 & 6.37 \\
\hline Clarc of energy distribution "fodder - egg white & $\begin{array}{c}0.0353 \\
(3.53 \%) *\end{array}$ & 0.02 & $\begin{array}{c}0.0384 \\
(3.84 \%)^{*}\end{array}$ & 0.01 \\
\hline Clarc of energy distribution "fodder - egg yolk" & $\begin{array}{c}0.1062 \\
(10.62 \%) \\
*\end{array}$ & 0.01 & $\begin{array}{c}0.1026 \\
(10.26 \%) \\
*\end{array}$ & 0.01 \\
\hline Clarc of protein transformation "fodder - egg white" & $\begin{array}{c}0.1029 \\
(10.29 \%) \\
*\end{array}$ & 0.02 & $\begin{array}{c}0.0997 \\
(9.97 \%)^{*}\end{array}$ & 0.01 \\
\hline Clarc of protein transformation "fodder - egg yolk" & $\begin{array}{c}0.0673 \\
(6.73 \%)\end{array}$ & 0.01 & $\begin{array}{c}0.0657 \\
(6.57 \%)\end{array}$ & 0.01 \\
\hline Clarc of energy distribution "fodder-egg mélange" & $\begin{array}{c}0.1415 \\
(14.15 \%) \\
*\end{array}$ & 0.01 & $\begin{array}{c}0.1410 \\
(14.10 \%) \\
*\end{array}$ & 0.01 \\
\hline Clarc of protein transformation"fodder-egg mélange" & $\begin{array}{c}0.1702 \\
(17.02 \%) \\
*\end{array}$ & 0.01 & $\begin{array}{c}0.1654 \\
(16.54 \%) \\
*\end{array}$ & 0.01 \\
\hline
\end{tabular}

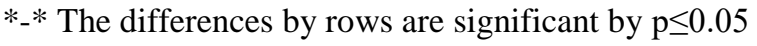

When comparing the gross energy produced from the albumen per layer for the whole experimental period, we found opposite differences -4.32 in the control group versus $3.99 \mathrm{MJ}$ in the experimental, respectively, because of the higher number of eggs. Results of $12.01 \mathrm{MJ}$ in the experimental and 11.52 MJ in the control groups were reported for the gross energy produced from the yolk.

The experimental group produced more crude protein from the albumen - $163.58 \mathrm{~g}$ versus $157.02 \mathrm{~g}$ for the control, as well as more crude protein from the yolk - 107.05 and $103.5 \mathrm{~g}$, respectively.

When calculating the Clarcs of energy distribution, statistically significant differences ( $p<0.05$ ) were observed between the experimental and control groups in all the three studied indicators. The energy distribution in the albumen was higher in the control group (0.0834), but in the yolk higher values of energy distribution were found in the experimental group (0.1062). Since the yolk is the main energy source, the Clarc of energy distribution in the melange was higher in the experimental group - 0.1415 vs. 0.1410 .

The protein transformation was higher in the experimental group both in the yolk and albumen and logically the transformation in the melange was higher -0.1702 versus 0.01654 .

\section{CONCLUSIONS}

For the whole egg laying period (mean 131 days) one layer is consumed mean $9.632 \mathrm{~kg}$ combined fodder, $112.99 \mathrm{MJ}$ metabolizable energy and $1.589 \mathrm{~kg}$ crude protein for the experimental group and $9.568 \mathrm{~kg}, 112.23 \mathrm{MJ}$, and $1.574 \mathrm{~kg}$ for the control group.

The following Clarc's of distribution/transformation are established:

Clarc of energy distribution:

-fodder-egg white -0.0384 for the control group and 0.0353 for the experimental group; 
-fodder-egg yolk - 0.1026 for the control group and 0.1062 for the experimental group;

-fodder-egg mélange -0.1410 for the control group and 0.1415 for the experimental group.

Clarc of (crude) protein transformation:

-fodder-egg white -0.0997 for the control group and 0.1029 for the experimental group; -fodder-egg yolk -0.0657 for the control group and 0.0673 for the experimental group; -fodder-egg mélange - 1654 for the control group and 0.1702 for the experimental group.

The birds became $10 \%$ bread wastes have significant higher $(p \leq 0.05)$ net utilization of fodder's energy and protein.

\section{REFERENCES}

1. Ayorinde, K. L. Guinea fowl (Numida meleagris) as a protein supplement in Nigeria, World's Poultry Science Journal, 47: 21-26, 1991.

2. Swierczewska, E., Wezyk, S. and Horbanczuk, J. Poultry farming Ed. Hoza, Warsaw. 1999. (in Polish)

3. Baeza, E., Lessire, M., Berri, C. and Juin, H. Compared carcass and meat characteristics of label and standard fowl. in Proc. XV Europ. Symp. on the Quality of Poultry Meat, Kusadusi, Turkey: 73-78, 2001.

4. Emmerson D. Commercial approaches to genetic selection for growth and feed conversion in domestic poultry. Poultry Science, 76, 8, (1), 1121-1125, 1997.

5. Gerzilov, V., V. Boncheva and P. Petrov, Egg production from dual purpose hen genotypes reared in free range system, Bulg. J. of Agric. Sci., 24 (1), 119-125, 2018.

6. Nahashon S. N., N. A. Adefope, A. Amenyenu and D. Wright. Laying Performance of Pearl Gray Guinea Fowl Hens as Affected by Caging Density, Production, modeling, and education, Poultry Sci. 85:1682-1689, 2006.

7. Pirgozliev V. and Rose SP. Net energy systems for poultry feeds: a quantitative review, World's Poultry Science Journal, 55(1): 23-36, 1999.

8. Penkov D and Genchev A. Methods for introduction of objective criteria for bioconversion of energy and nutrients along the feed - animal products chain in meet-type poultry farming, Journal of Central European Agriculture, 19 (2), 270-277,2018, DOI: /10.5513/JCEA01/19.2.2152

9. Dobrovolskiy, V.V. Introduction to biogeochemistry. Moscow: Visshaya shkola, 1998.
PENKOV D., et al.

10. Baykov, B. An objective method for assessment of the movement of the chemical elements in anthropogenic ecosystem (domestic animal farms). Toxicology Environmental Chemistry, 42, 227-233, 1994.

11. Yadav, D. S., Shrivastava, M., Singh, J. P.and Mishra, A. K. Effect of replacement of maize with bakery waste in broiler ration. International Journal of Agricultural Sciences and Veterinary Medicine, 2 (1), 28-33, 2014.

12. Al-Tulaihan, A., Najib, H.and Al-Eid, S. The nutritional evaluation of locally produced dried bakery waste (DBW) in the broiler diets. Pakistan Journal of Nutrition, 3 (5), 294-299, 2004. DOI: /10.5513/JCEA01/21.3.2658.

13. Krička, T., Janjecic, Z., Bilandzija, N., Bedekovic, D., Voca, N., Matin, A., Jurisic, V.and Grubor, M. Nutritional usability of thermal treated white and brown bread in broiler feed, Journal of Central European Agriculture, 20 (3), 788-795, 2019.

14.Penkov D.and Chobanova S., 2020, Metabolizable energy and true digestibility of the protein of extruded of akery by - products (bread wastes) in balanced experiments with poultry, Journal of Central European Agriculture, 21(3),517-521, 2020, DOI: /10.5513/JCEA01/21.3.2658.

15. AOAC international. Official methods of analysis of AOAC (18 edition, rev. 2), Association of Official Analytical Chemists Intern., Gaithersburg, MD, USA, 2007.

16. Schiemann, R., K. Niering, L. Hoffmann, W. Jench and A. Chudy, Energetische Fuetterung und Energienormen. VEB Deutscher Landwirtschaftsverlag, Berlin, 1971.

17.Penkov D., and Grigorova S., Energy and protein net utilization in the chain "feed-meat" in rabbit's fattening trough the introduction of the "Clarc energy distribution/Clarc protein transformation" system, $J$. of BioScience and Biotechnology, Vol. 9 No. 1 : 65-68, 2020 , ISSN 1314-6246

18. Angelov A. Productive characteristic of local population of Guinea fowls (N. meleagris) in the Republic of Bulgaria, $\mathrm{PhD}$ Thesis, Agr.Univ.-Plovdiv, pp 239, 2018.

19. Song K. T., Choi S. H. and Oh H. R. A Comparison of Egg Quality of Pheasant, Chukar, Quail and Guinea Fowl. AsianAustralasian Journal of Animal Sciences, 13 (7): 986-990, 2000.

20. Dudusola I. O., Comparative evaluation of internal and external qualities of eggs from quail and guinea fowl International Research Journal of Plant Science.;1(5):112-115, 2010. 